\title{
NESTED METHODOLOGICAL APPROACHES FOR CLUSTER POLICY EVALUATION: AN APPLICATION TO THE BASQUE COUNTRY
}

\author{
This is a Draft Version of a paper that will be published in a \\ forthcoming issue of the journal Regional Studies
}

\author{
Mari José Aranguren \\ Orkestra - Basque Institute of Competitiveness and Deusto Business School, Spain \\ (Mundaiz, 5o, San Sebastian 20012, Spain, mjarang@orkestra.deusto.es)
}

\section{Xabier De La Maza}

Orkestra - Basque Institute of Competitiveness and Deusto Business School, Spain (Mundaiz, 5o, San Sebastian 20012, Spain, xdelamaz@orkestra.deusto.es)

\section{Mario Davide Parrilli}

Orkestra - Basque Institute of Competitiveness and Deusto Business School, Spain (Mundaiz, 5o, San Sebastian 20012, Spain, m.d.parrilli@orkestra.deusto.es)

\section{Ferran Vendrell-Herrero}

Universitat Politècnica de Catalunya, Barcelona Tech, Spain

(Plaça del Pla de Palau 18, o80o3 Barcelona, ferran.vendrell@upc.edu)

\section{James R. Wilson}

Orkestra - Basque Institute of Competitiveness and Deusto Business School, Spain (Mundaiz, 5o, San Sebastian 20012, Spain, jwilson@orkestra.deusto.es)

\begin{abstract}
:
This paper explores the evaluation of cluster policies designed to support cooperation and networking. We examine the case of the long-running Basque policy, where support is provided for 'cluster associations'. We first examine empirically the effects of the cluster associations on firm productivity performance, alongside other variables including agglomeration and firm behavioural characteristics. The results provide some weak evidence for the existence of additionality associated with the policy. We complement this empirical work with context-specific knowledge of the policy in question to show that the nesting of both empirical and contextual approaches is crucial for effectively evaluating such policies.
\end{abstract}

Keywords: policy evaluation, cluster policy, cluster association, mixed methodologies JEL Codes: L2O, L60, O25, R58 


\section{INTRODUCTION}

There is widespread acceptance, certainly within Europe, of the need to design policies such as cluster policies that nurture and support cooperative relationships among groups of firms. Despite this acceptance there remains a shortage of thorough evaluations that enable us to understand the impacts of these policies. The intangible outcomes of such policies and their systemic character give rise to specific evaluation demands that are difficult to meet using any one evaluation technique. In this paper we argue the importance of nesting empirical analysis within a contextual understanding of the policy, an approach that is applied to the long-standing cluster policy of the Basque Country region of Spain.

Policies designed to nurture and support cooperative relationships between economic agents (firms and support organizations) have been increasingly employed during the last two decades. This has corresponded both with the rise of systemic concepts of innovation (FREEMAN, 1987; LUNDVALL, 1992; NELSON, 1993; COOKE et al., 1998) and with the establishment and growing popularity of the 'cluster' concept (PORTER, 1990, 1998, 2003; SCHMITZ, 1995). Indeed policies designed to nurture and support the development of strong clusters of firms and other production-related organisations are today widespread. This is despite varied critique around the theoretical and empirical basis of the cluster concept (BENNEWORTH and CHARLES, 2001; MARTIN and SUNLEY, 2003; LORENZEN, 2005; BELUSSI, 2006; PITELIS et al., 2006).

The theoretical benefits of conscious and unconscious relationships between geographically proximate groups of firms are rooted in the work of Alfred MARSHALL $(1907,1919)$ on industrial districts, and have been analysed from a range of different perspectives and contexts (PIORE and SABEL, 1984; BECATTINI, 1991; SAXENIAN, 1994; SCHMITZ, 1995). 
Arguably the most influential figure in the recent and remarkable policy acceptance of the cluster concept has been Michael Porter. PORTER (1998, p.199) defines a cluster as "a geographically proximate group of interconnected companies and associated institutions in a particular field, linked by commonalities and complementarities", a definition that is frequently criticised for its broadness, but one which has found particular favour with policy-makers (MARTIN and SUNLEY, 2003).

Cluster policies ${ }^{1}$ are a classic example of a 'soft policy'; rather than dealing in subsidies for specific production- or innovation- related activities, they focus support on fostering a general atmosphere conducive to co-operative relationships between agents. The extent of their uptake can be seen in a recent report identifying 69 distinct national cluster policy programmes in Europe alone, with regional programmes also found in 17 European countries (OXFORD RESEARCH, 2008). Yet for a policy focus with such wide extension there is a shortage of analysis evaluating the effectiveness of individual policies in meeting their specified aims (usually defined in terms of productivity, competitiveness, employment generation, etc.). In part this is due to the inherent methodological difficulties in evaluating cluster policies, whose direct outcomes are usually intangible (e.g. wider space for debate on common business issues that may lead to proper solutions in the long term, higher generalized trust and social capital, significant knowledge spillovers from cluster policy to non-associated companies and to other agents unrelated to the specific cluster). It is also due to the sheer variety of specific policies that fit within this broad policy family, rendering generalisation of results and implications extremely difficult. ${ }^{2}$

Policies oriented towards stimulating cooperative relationships are typically rooted in an array of industrial, regional, science and technology or development policies. Cluster policies are no exception, and the reality of the policy legacy in many places is a mix of 
policies with 'cluster elements' rather than a dedicated/pure cluster policy (OECD, 2007; Borrás \& Tsagdis, 2008; PARRILLI et al., 2008). Moreover, cluster policies occur within a general policy environment in which a multitude of policies directed by governments at different geographical scales interact together.

There are therefore specific demands in evaluating cluster policies. On the one hand there is a need to combine different evaluation approaches. Given the above-mentioned difficulties and the systemic character of policy, as SCHIEMEDEBERG (2010; p.404) concludes, "using only a single evaluation method will provide a very limited view on the cluster policy programme". This makes it critical to choose a combination of evaluation methods that together are appropriate for the specific evaluation question. On the other hand, there is need to recognise that cluster policies generate non-measurable impacts (in the short term), and indeed that in some cases the most significant effects of these policies are produced in non economic spheres (DIEZ, 2002; FROMHOLD-EISEBITH and EISEBITH, 2005, 2008). This paper seeks to respond to these two needs. A combination of empirical analysis and context-specific knowledge of the policy in question provides a basis for discussing both tangible and intangible outcomes of policy as well as its systemic character.

Our contribution is based around an examination of one of the longest-standing cluster policies. The Basque Country region in Spain was a pioneer in adopting a Porterian approach to promoting clusters in the early 1990s, and has maintained a cluster policy to this day. Specifically, and like many other cluster policies, support exists for the establishment and operation of a series of Cluster Associations (CA). Our analysis has two parts. We first undertake an empirical study to explore the direct effects on firm performance (measured in productivity and productivity growth) of: (i) association membership (which can be related to the policy); and (ii) agglomeration (which can be 
related to firm location decisions based on the importance of external economies). We also include here the driver (iii) 'policy targets' for selected priorities defined within the Basque autonomous region (e.g. innovation and quality management measured through $\mathrm{R} \& \mathrm{D}$ expenditure and ISO certifications), and (iv) a few standard and observable control variables at the firm level such as age of company, employment level and legal status. The results provide some evidence that members of CAs have larger productivity and productivity growth than non-members of CAs. We then complement this empirical work with context-specific knowledge of the policy in question as a means to include also relevant qualitative inputs and outcomes (e.g. mutual effects between cluster policy and other business promotion programmes, knowledge spillovers from activities developed by CAs to non-associated firms). We argue that the nesting of both empirical and contextual approaches is crucial for effectively evaluating cluster policies.

The paper is structured as follows. In section 2 we provide theoretical background on clusters and the basis for cluster policies, and discuss their evaluation. Section 3 then outlines the Basque cluster policy and previous attempts to evaluate its effectiveness. Section 4 presents the empirical study, and section 5 is dedicated to a contextual discussion of these results that highlights the limitations of the exclusive use of statistical approaches to evaluating cluster policies. Finally, we make some concluding comments on future lines of research in section 6 .

\section{THEORETICAL PREMISE AND EVALUATION OF CLUSTER POLICIES}

\subsection{Clusters and Cluster Policies}

The theoretical premise for the benefits of industrial clusters has its deepest roots in the seminal study of agglomeration economies of MARSHALL $(1907,1919)$. Since then 
economists have tried to explain the effects derived from geographic concentration of economic activity. Following GLAESER et al. (1992), it is common to distinguish between 'Marshall-Arrow-Romer (MAR)' and 'Jacobs' externalities. MAR externalities occur because the concentration of a specific industry within a geographic area facilitates knowledge spillovers across firms (lower costs of communication and transactions), while Jacobs externalities are based on inter-industry knowledge externalities, which are most likely to appear in large and diverse urban areas. There is a large empirical literature that has analysed various aspects of agglomeration impacts in terms of both Jacobs and MAR externalities. See, for example: GLAESER et al., (1992); AUDRETSCH and FELDMAN (1996); PACI and USAI (2000); DURANTON and PUGA (2001); GREUNZ (2004); MARTIN et al. (2008b); SPENCER et al., (2009).

Clusters are not simply an agglomeration concept however. Agglomeration per se implies potential costs as well as hypothesised benefits; congestion of infrastructure use and labour market pressures are two clear examples of negative externalities. Moreover the benefits require more than agglomeration. They rely on cooperation between agents to acquire competitive advantages; for example, sharing the costs of input purchases or risky innovation projects, or joint access to finance or international markets. Credit and export consortia, production cooperatives, etc. provide examples (PIORE and SABEL, 1984; BECATTINI, 1991; SCHMITZ, 1995). Moreover innovation is increasingly recognised as being network-oriented, i.e. rooted in complex processes of interactions and cooperation among a variety of actors within the innovation system (suppliers, competitors, employees, customers/users, research institutions, regulatory bodies and so on) (VON HIPPEL, 1988; FREEMAN, 1991; LUNDVALL, 1992; POWELL et al., 1996). 
These considerations create a persuasive rationale for policies that are focused on facilitating co-operative network relationships. Indeed, based on these theoretical premises (i.e. agglomeration economies and cooperation), alongside well-known success cases such as the Italian industrial districts (PIORE and SABEL, 1984; BECATTINI, 1991) and Silicon Valley (SAXENIAN, 1994), policy-makers have seized in particular upon PORTER's (1990, 1998, 2003) neat packaging of the 'cluster' concept. An increasing number of authorities at supra-national, national, regional and even local level have integrated the 'cluster' concept into their policy discourse (OECD, 1999; 2007; ISAKSEN and HAUGE, 2002; SÖLVELL et al., 2003; MARTIN and SUNLEY, 2003; PITELIS et al., 2006; NAUWELAERS and WINTJES, 2008; BORRÁS and TSAGDIS, 2008). Complementarily, the plethora of cluster policies has been supported by the devolution processes that many countries are experiencing and the increasing private/public collaboration in projects derived from EU structural funds (LAGENDIJK and CONRFORD, 2000; RODRÍGUEZ-POSE and GILL, 2003).

Many cluster policies are built around the policy tool of establishing and/or supporting institutions for collaboration (IFCs). Here financial, infrastructural and/or technical support is given for the formalisation of cooperative relationships between agents in some form of association or network. Such institutions are of course not only associated with cluster policies; some have long been present in the form of trade associations, entrepreneurial networks, industry associations, etcetera. Cluster initiatives, or cluster associations, represent a particular form of IFC in which groups of firms, research and educational institutions, government agencies, and others come together to improve the competitiveness of a specific, geographically-bound 'cluster' of productive activities (PORTER and KETELS, 2009). Cluster initiatives can be initiated by companies, universities, or government agencies, but research indicates that their success depends on 
the active involvement of all agents in setting and pursuing an agenda, rather than on who initiated the effort (SÖLVELL et al., 2003; AHEDO, 2004; PARRILLI, 2004; FROMHOLDEISEBITH and EISEBITH, 2005, 2008; ARANGUREN ET AL., 2009).

\subsection{Cluster Policy Evaluation}

Given the growth of these policies, the evaluation and monitoring of the management of cluster associations has become a key topic (TERSTRIEP, 2007). Such evaluation is important because cluster association initiatives have limited resources, both in human and financial terms, and they need to strategically prioritise their activities. Evaluation of cluster associations also plays an important legitimisation role, both within the cluster of firms and externally among policy-makers. However, the evaluation of the impacts of the cluster policies themselves in terms of their stated aims and objectives is less developed: see SCHMIEDEBERG (2010) for an overview.

While evaluation of public policies is widely acknowledged as critical in enabling better decision-making processes and ensuring future policy effectiveness (TUROK, 1990; RAINES, 2002; STOREY 2000, 2004; OCDE, 1999, 2007; NAUWALAERS AND WINTJES, 2008; BORRÁS and TSAGDIS, 2008; PARRILLI, 2008), problematically cluster policies face distinct challenges in their evaluation. The tangible outcomes that can be explicitly linked to the financial inputs of many policies are frequently absent in policies that focus on facilitating collaboration. Thus their evaluation is more of a tool for ongoing improvement than an ex-post control of whether the policy assistance led to a specific outcome. Indeed, in a context of overlapping policies evaluation can support the better integration of different processes, generating constant feedback for agents that will improve the real outcomes of various inter-connected policies (NAUWALAERS and WINTJES, 2008; BORRÁS and TSAGDIS, 2008). 
The continuous adaptation of policies to socio-economic reality is particularly relevant in regional policy-making, where aspects such as trust, social capital, and system connectivity are both central and complex in terms of cause-effect relationships (ASHEIM, 2010). Here the difference between ex-post and continual evaluation processes is crucial, because while ex-post evaluation is summative in nature (it tries to measure policy effects and impacts), ongoing evaluation processes are formative in nature (enabling policy-learning through the lifespan of the policy). Corresponding with the evolution from classical conceptions of policy towards more systemic ones, evaluation should also evolve to dynamic processes of interaction with and feedback from the targeted agents, so as to facilitate reflection and continuous policy adaption.

This creates an additional challenge for academic analysis of the impacts of cluster policies: how to integrate traditional empirical techniques for analysing tangible impacts (policy additionality), with contextual elements capable of providing a wider understanding of the effects of the policy? In fact, the relevance of contextual elements is justified by the existence of organizational, social, institutional and cultural inputs that may produce meaningful effects only in the long-run. However, while both approaches give important insights, they are rarely treated together. Most academic analyses evaluating cluster policies have focused on one or the other; typically either case studies highlighting contextual elements (see for example: PARRILLI, 2004; PITELIS et al., 2006; ARANGUREN et al., 2008; BORRAS and TSAGDIS, 2008) or evaluations seeking to quantify direct effects in terms of a specific 'hard' outcome (see for example: HUGGINS, 2001; MCDONALD et al., 2007; MARTIN et al., 2011a; 2011b; DE LA MAZA et al., 2012). The reality of cluster policies, however, is that the relationships between tangible and intangible effects are extremely difficult to de-limit. As a consequence, while analyses showing tangible, 
quantifiable additionality are attractive to policy-makers seeking to legitimise their policies, such analyses can be misguided if they occur in isolation without a contextual appreciation of the policy.

\subsection{Analytical strategy}

This paper attempts to show that the inherent complexities in evaluating cluster policies necessitate the integration of empirical and contextual understanding. The first step consists of focusing analysis on a particular geographical context, in this case the cluster policy implemented since the early 1990 s in the Basque Country region of Spain, which is introduced in the next section. This is an important departure point because all of the clustered firms in the area receive a homogeneous policy treatment.

The second step in the analytical strategy is to formalise a theoretical model to be tested with firm-level data. Given that the stated overall aim of the cluster policy is to increase the competitiveness of the Basque Country, and following PORTER's (1990; p. 84) argument that "only meaningful concept of competitiveness at national level is productivity", specifically the capacity of "companies to achieve high levels of productivity - and to increase productivity over time", the objective variable is firm competitiveness measured as both productivity level and productivity growth. This will be modelled as a function of a set of variables including cluster policy, geographical agglomeration, industry, and distinctive firm characteristics. Equation 1 specifies the basic theoretical model. ${ }^{3}$

\section{Equation 1}

$$
\begin{gathered}
Y_{i}=\propto+\beta_{1} \text { CLSTER }_{i}+\beta_{2} \text { INDAGG }_{i}+\beta_{3} \text { SECAGG }_{i}+\beta_{4} R \& D_{i}+\beta_{5} \text { TMQ }_{i}+\beta_{6} \text { EMQ }_{i} \\
+\beta_{7} \text { LEGAL }_{i}+\beta_{8} \text { SECTOR }_{i}+\varepsilon_{i}
\end{gathered}
$$


After an empirical analysis of the impacts of the cluster policy, the final step in the analytical strategy is to return to a consideration of the context through a reflective analysis of the results in the light of a set of qualitative knowledge about the functioning of the policy.

\section{CASE CONTEXT: BASQUE CLUSTER POLICY}

At the beginning of the 1990 s the Basque Country was in a process of economic decline. Its industry mostly competed on cost, a competitive advantage that was now in danger, particularly in the light of the impending consolidation of a common European market. Policy responses were sought to construct new competitive advantages, and in particular the Basque government pioneered in, together with Catalonia (Spain) and Scotland (UK), the establishment of a Porterian cluster policy that is still in operation today (BROWN, 2000; KETELS, 2004).

The specified aim of the Basque cluster policy is the improvement of the competitiveness of firms and the region through cooperation in strategic projects related to three main areas: technology, quality management and internationalisation. This is operationalised by the Department of Industry, Trade and Tourism (DITT) through support for Cluster Associations (CAs). These are institutions for collaboration whose main objective is to improve each cluster's competitiveness by facilitating and fostering cooperation/collaboration among their members, including firms, R\&D centres, universities, government and so on. Today there are 11 priority CAs supported by the DITT, alongside a $12^{\text {th }}$ supported by the Department of Transport (table 1 ). 
Tentative efforts to evaluate the effectiveness of the cluster policy in the Basque Country were first made in 1998, when the DITT initiated a policy reflection process. AHEDO (2004) analysed these first evaluation steps and identified three main conclusions. Firstly, it had been an adequate industrial policy with regards prioritising public resources. Secondly, there had been a low level of mergers and strategic alliances, but an important increase in inter-firm relations (e.g. export consortiums and R\&D projects). Finally, the associated firms were not inclined to self-finance the whole budget of the CA activities and hence continued public aid was regarded as necessary.

Simultaneously, a new line of research on policy evaluation was initiated by ARANGUREN and NAVARRO (2003), leading to a series of research projects defined by a group of researchers in cooperation with the DITT and some CAs (see ITURRIOZ et al., 2006; ARANGUREN et al., 2008; ARAGÓN et al., 2010; ARAGÓN et al., 2012a, 2012b). These projects have complemented other assessment instruments, such as the required annual planning and control process of the CAs. The studies have employed a range of methodological approaches to evaluation, and limitations of each have confirmed the importance of measuring both the tangible and intangible impacts of policy-supported CAs on firms' competitiveness so as to generate a holistic understanding of the policy.

\section{EMPIRICAL ANALYSIS: SEARCHING FOR DIRECT ADDITIONALITY EFFECTS}

The aim in this section is to establish the additionality (or not) of this policy in terms of its specific aim of improving the competitiveness of the firms that form the CAs. We undertake

a comparative analysis of the population of supported and non-supported firms in terms of their productivity performance. We analyse descriptive statistics and then estimate 
regression models to determine the impacts of cooperation (in this case 'association membership') and agglomeration, controlling for other variables that may determine individual firm productivity performance. In doing this we employ two types of samples: one representing the total firm population, and one using a 'matching' process. Following SCHMIEDEBERG (2010, p. 399), "the matching sample is a quasi-simulation approach that tries to overcome the shortcomings of observational data by building 'twin' pairs of treated and non-treated elements". Estimating a propensity score (ROSENBAUM and RUBIN, 1983), this procedure assigns to each 'supported firm' a 'non-supported firm' with similar observable characteristics. After this step the subsamples of treated and non-treated firms should be comparable, "so that the average treatment effect on the treated firm can be estimated" SCHMIEDEBERG (2010, p. 399).

\subsection{Construction of the sample and matched sub-sample}

Our dataset is constructed from a combination of two information sources: the $S A B I-$ Informa database (economic results from Spanish firms) and the DIRAE database (economic activity directory from EUSTAT, the Basque Statistical Institute). The list of CA members is comprised of firms that joined CAs in 2002 or earlier. We selected information for two years (2002 and 2008). This is a period of relatively stable growth across the whole economy, implying similar conditions for all firms. It is also a period in which the selected CAs had already become relevant agents within their production systems; hence a mature stage of the policy. Geographically, our data covers the three provinces and 20 counties of the Autonomous Community of the Basque Country. In terms of economic activity, we consider firms belonging to sectors that correspond with those supported by the cluster policy (see Table 2). 
Information about the cluster policy and the members of each CA is public. We merged the list of members of the 12 cluster associations with the aforementioned databases. In 2002 the total sample contains 5525 observations, but there are only 3432 observations in 2008 . . With regards members of the CA we observe 176 firms in 2002 and 127 in 2008 . Consequently, their likelihood of survival is $72,15 \%, 10 \%$ larger than the rest of the sample (61,77\%). Given that the survival rate of CAs firms is larger than their non-CA counterparts, the sample at the end of the period (2008) under-represents unsuccessful non-CAs. Therefore, a simple OLS regression of labour productivity (or labour productivity growth) on cluster membership will lead to downward-biased estimates. Furthermore, a simple OLS would incur in a loss of 2,093 observations. The risk of biased estimates and the loss of information that entails the use of the OLS will be addressed through the implementation of a Heckmann (1979) sample selection model. This method will also provide statistical validity (or not) for the higher survival rate of CAs in comparison with non-CAs.

We collected data using processes that were as consistent as possible in order to obtain comparable information about clustered and non-clustered firms. However, some biases in terms of size, location or distribution could arise between both samples. In order to evaluate the importance of those biases we performed a probit regression, using CA membership as the dependent variable. As explanatory variables we included the logarithm of firms' employment and age in 2002, a set of dummy variables describing whether firms are developing R\&D or quality standards, the sector and location in which firms operate and their juridical form. ${ }^{4}$ The model is significant $\left(\mathrm{LR} \mathrm{Chi}^{2}=474.42, \mathrm{prob}>\mathrm{Chi}^{2}=0.000\right)$, the pseudo- $\mathrm{R}^{2}$ equals 0.307 , and most of the explanatory variables are significantly different from zero. Moreover, following propensity score-matching literature, we estimated the matching scores from the probit (Leuven and Sianesi, 2003) and used the nearest 
neighbour without replacement methodology (Deheija and Wahba, 2002) to identify comparable pairs. The matching was carried out by choosing the caliper that assured sufficient proximity between pairs. More precisely, we required the difference of propensity scores between groups to be non-significant as long as we kept the maximum number of firms in the sample. When the caliper is 0.40 , the average propensity scores for clustered and non-clustered firms are 0.245 and 0.210 respectively. We could not reject the null hypothesis that they were equal $(\mathrm{p}$-value $=0.215)$. This matched sub-sample contained 240 firms, 120 of each type. Performing the probit again with the sub-sample, the model becomes insignificant $\left(\mathrm{LR} \mathrm{Chi}^{2}=10.43\right.$, prob $\left.>\mathrm{Chi}^{2}=0.999\right)$, the pseudo- $\mathrm{R}^{2}$ equals 0.032, and the explanatory variables are statistically not different from zero. This procedure establishes a high confidence in the results achieved in the full sample and the matched sub-sample.

\subsection{Data Analysis}

The overall objective is to measure how firm productivity is influenced by the most relevant cluster drivers: agglomeration economies5, cooperation ('association membership'), and behaviour in the areas in which cluster policy is designed to make a difference (innovation, analyzed here through presence of R\&D activities, and quality, analysed here by ISO certifications in TMQ and EMQ). ${ }^{6}$ The age, employment level, legal structure and industry of firms are also controlled for. Table 3 provides an explanation of all variables. A descriptive analysis is first undertaken to identify the different characteristics of firms that are members of CAs vis-a-vis firms that are not. Table 4 presents basic descriptive statistics (mean and standard deviation) for these two groups of firms.

[TABLES 3 AND 4 ABOUT HERE] 
We can observe from both samples that associated firms are on average significantly larger than non-associated firms, and demonstrate higher productivity both in 2002 and in 2008 . Moreover, the absolute increment in productivity is also higher among associated firms, as is relative productivity growth. With regard to the behaviour measures, the two groups of firms in both samples show substantial differences in propensity to undertake R\&D and adoption of ISO certification (TMQ and EMQ). In the total sample, associated firms achieve double or more of the results of non-associated firms. Differences between associated and non-associated firms in the matching sample are also substantial. This variation may be interpreted in different ways. It might be that technology-based firms are more likely to join CAs, possibly due to higher absorptive capacity which helps them reap higher benefits from interactions with other companies in the cluster. Alternatively or complementarily, this outcome might be explained by the fact that larger firms tend to associate, possibly for a series of advantages that they want to achieve in cooperation (e.g. controlling the local market or improving coordination in the value chain).

\subsection{Econometric analysis}

The aim of the econometric analysis is to isolate the impact of being a CA member, as opposed to agglomeration and other factors, on firms' productivity performance. The empirical models are based on the theoretical premises discussed in section 2 and the Basque cluster policy context introduced in section 3. With this analysis we will be able to detect patterns at the beginning and end of our observation period and, most critically, the evolution in performance between 2002 and 2008. With regards evolution we run regressions for both absolute and relative change. The following four models are therefore estimated:

Equation 2 (OLS for full and matched sub-sample) 


$$
\begin{aligned}
\ln Y_{i 2002}=\propto+ & \beta_{1} \text { CLUSTER }_{i}+\beta_{2} \text { INDAGG }_{i 2002}+\beta_{3} \text { SECAGG }_{i 2002}+\beta_{4} R \& D_{i}+\beta_{5} \text { TMQ }_{i} \\
& +\beta_{6} \text { EMQ }_{i}+\beta_{7} \text { LEGAL }_{i}+\beta_{8} \text { SECTOR }_{i}+\varepsilon_{i}
\end{aligned}
$$

Equation 3 (Heckman for full sample and OLS for matched sub-sample)

$$
\begin{aligned}
\ln Y_{i 2008}=\propto+ & \beta_{1} \text { CLUSTER }_{i}+\beta_{2} \text { INDAGG }_{i 2008}+\beta_{3} \text { SECAGG }_{i 2008} \\
& +\beta_{4} \text { REDOUNT }_{i 2008}+\beta_{5} \operatorname{lnLABCOST} \operatorname{COUSO}_{i 2008}+\beta_{6} \operatorname{lnGDPPC}{ }_{i 2008}+\beta_{7} R \& D_{i} \\
& +\beta_{8} \text { TMQ }_{i}+\beta_{9} \text { EMQ }_{i}+\beta_{10} \text { LEGAL }_{i}+\beta_{11} \text { SECTOR }_{i}+\varepsilon_{i}
\end{aligned}
$$

Equation 4 (Heckman for full sample and OLS for matched sub-sample)

$$
\begin{aligned}
& \ln \Delta Y_{i}=\ln Y_{i 2008}-\ln Y_{i 2002}= \\
& \propto+\beta_{1} \text { CLUSTER }_{i}+\beta_{2} \ln Y_{i 2002}+\beta_{3} I N D A G G_{i 2002}+\beta_{4} \text { SECAGG }_{i 2002} \\
& +\beta_{5} R \& D C O U N T_{i 2008}+\beta_{6} \operatorname{lnLABCOST}_{i 2008}+\beta_{7} \operatorname{lnGDPPC}{ }_{i 2008}+\beta_{8} R \& D_{i} \\
& +\beta_{9} T M Q_{i}+\beta_{10} E_{i} Q_{i}+\beta_{11} L_{E G A L_{i}}+\beta_{12} \text { SECTOR }_{i}+\varepsilon_{i}
\end{aligned}
$$

Equation 5 (Heckman for full sample and OLS for matched sub-sample)

$$
\begin{aligned}
\ln R \Delta Y_{i}=\frac{\ln Y_{i 2008}-\ln Y_{i 2002}}{} & \ln Y_{i 2002} \\
& \propto+\beta_{1} \operatorname{CLUSTER}_{i}+\beta_{2} \text { INDAGG }_{i 2002}+\beta_{3} \text { SECAGG }_{i 2002}+\beta_{4} R_{\text {R DCOUNT }}{ }_{i 2008} \\
& +\beta_{5} \operatorname{lnLABCOST}_{i 2008}+\beta_{6} \operatorname{lnGDPPC}_{i 2008}+\beta_{7} R \& D_{i}+\beta_{8} \text { TMQ }_{i}+\beta_{9} E M Q_{i} \\
& +\beta_{10} \text { LEGAL }_{i}+\beta_{11} \text { SECTOR }_{i}+\varepsilon_{i}
\end{aligned}
$$

Where $\mathrm{i}$ represents each firm and $\varepsilon_{\mathrm{i}}$ is the error term. It is worth mentioning that the assumption of independence and equal variance between the error terms would not hold if some firms systematically used unobserved inputs in excess of the average. This may lead to potential misspecifications of coefficient values (HUBER, 1967, WHITE, 1982). Moreover, our dataset has a multilevel nature as long as some of the explanatory variables are measured at county level. This can induce downward biased standard errors. We control for all those biases applying clustered (by county) robust (to Heteroskedacity) standard errors (WOOLDRIDGE, 2003). The results from estimating these four empirical models for the two samples are reported in Tables 5 and 6.

[TABLES 5 and 6 ABOUT HERE] 
In the case of the full sample, where we perform OLS for Equation 2 and Heckman's (1979) selection model for Equations 3, 4 and 5, the $\mathrm{R}^{2}$ ranges from 0.05 to 0.12 . In the first stage (Probit) of the regressions run with the Heckman selection model we included cluster membership, age of the firm in 2002, labour size in 2002 and sector dummies. The Lambda Mills is not statistically significant which implies that there is not significant relation between the fact of survival until 2008 and the predicted productivity and productivity growth.

In all the models of the full sample the CLUSTER variable is positive and significant in the regressions related to both absolute and relative changes in productivity. Thus there are differences in the average productivity performance between CA members and nonmembers that appear as significant when controlling for other variables. In addition the results of the Heckman selection model indicate that members of the CA have significantly more likelihood of survival than non CA members. Overall, this evidence could be interpreted as indicative of additionality (in labour productivity and survival) from the policy. The industrial agglomeration (INDAGG) variable is positive in the absolute change and negative in the relative change regression, and in both cases is not statistically significant in explaining differences in productivity across firms in the period 2002-2008, while sectoral agglomeration (SECAGG) is negative and not significant in both cases. Firm behaviour with regards R\&D and quality management (TMQ and EMQ) does not appear to be significant in determining changes in firm productivity, and the same happens with the variables of labour cost and GDP per capita. In the case of R\&D, technical (TMQ) and environmental (EMQ) activities have a negative sign in both the absolute change regression and the relative change regression. 
The results of the matched sub-sample have a larger explanatory capacity (the $\mathrm{R}^{2}$ ranges from 0.18 to 0.61 ) and can be interpreted in a similar way. The productivity level regression from 2002 indicates that there was no self-selection effect at the beginning of the period, while in the 2008 regression the CLUSTER variable is positive and significant. When applying regressions to the absolute and relative models, there are positive signs but there is no statistically significant effect from belonging to a CA. The difference is higher in the relative change model. Again the sectoral agglomeration (SECAGG) variable is found to be negative although not significant for the period 2002-2008, while industrial agglomeration (INDAGG) demonstrates positive and not significant values. In terms of the effects of the firm behaviour variables on productivity changes: the R\&D, technical management (TMQ) and environmental quality (EMQ) variables have a negative effect in both regressions, although they are not significant. Regarding (county) labour cost the sign of the variable is negative and significant in both absolute and relative labour productivity regressions, suggesting that productivity growth is higher in those counties where labour cost is low. Finally, the GDP per capita in each county is positively linked to changes in productivity.

The key question asked from this type of statistical analysis is to what extent the cluster policy demonstrates additionality that justifies public intervention. On this question the results deliver weak positive evidence regarding effects on labour productivity growth. While the overall positive effect of belonging to a CA is supported consistently by different specifications and samples, the changeable nature of signs and significance on many variables highlight the caution with which such analysis should be treated. Indeed, in general the results related to the variables analysed do not seem particularly significant or steady over time. Moreover, definite conclusions on additionality in the case of such relationship-driven policies are difficult to reach precisely because the systemic and tacit nature of the policy means that it cannot be entirely captured by the indicators available. 
Thus while the results presented are an important input into the evaluation of such a policy, they should be positioned alongside other inputs. We turn in the next section to a detailed discussion of these limitations through a qualitatively-informed contextual analysis of what may be happening in the case of the Basque cluster policy.

\section{CHALLENGES IN INTERPRETING THE IMPACTS OF CLUSTER POLICIES: A CONTEXTUAL ANALYSIS OF THE BASQUE CASE}

There are inherent difficulties in evaluating the impacts of cluster policies. These are illustrated by the empirical analysis of the previous section and evidenced by the lack of robust formal analysis of such policies to date in the literature. The difficulties arise for two key reasons. Firstly these policies are focused above all on qualitative relationships, dealing with intangible changes in behaviour. Cluster policies are generally designed to promote (the benefits of) co-operation, alongside competition, between groups of firms and related institutions. Their focus is on relationships, and on their underlying determinants such as trust and social capital. So, unlike in 'harder' policies (e.g. financial subsidies; investment in infrastructures), the relationship between policy inputs, intermediate outputs and expected policy outcomes is unclear and extremely difficult to delimit statistically. Secondly, we are dealing with systemic policies that interact at different levels and in broader frameworks, such as systems of innovation. Interactions and interdependencies among different components of clusters and innovation systems, for example, are crucial for the development of systemic learning processes.

We are left with the challenge of how to overcome these difficulties in making a broad assessment of how well distinct policies within a given system are contributing to the overall development of that system. While empirical analysis such as that of the previous section, 
or the ones conducted recently by MARTIN et al. (2011a, 2011b), can provide an important background to the functioning of an individual policy, on its own it cannot be pushed too far in making precise impact assessments given the systemic and intangible characteristics of the policy. As such, cluster policies require a broader evaluation approach than that presented in the previous section. Specifically, evaluation should be seen more as a tool for ongoing improvement and adjustment rather than as an ex-post control of whether the policy assistance led to a specific outcome.

These arguments can be illustrated in the Basque case through a contextual analysis of a series of factors that should be considered alongside the empirical analysis presented previously. This is based on accumulated academic and consultancy knowledge over two decades of cluster development and policy in the Basque Country. Due to its systemic nature, we underline at least three areas that imply important contextual considerations to complement the former empirical analysis.

1. There could be impacts and results within clusters that are caused by different factors. So it is difficult to assign the impacts only to the cluster policy.

To evaluate the impact of a policy, it is first necessary to know the aims of the policy. Evaluation should be related to the kind of additionality that the policy wants to generate. The Basque cluster policy aims at improving the cluster associations' members' competitiveness through cooperation. So it seeks to generate output additionality through behavioral additionality (GEORGHIOU, 2004). Implicitly, competitiveness is understood as productivity. The first key problem with the evaluation of the policy therefore concerns the multidimensional factors that affect firm productivity and competitiveness. There are a wide variety of factors that influence the productivity levels and growth trajectories of firms; 
in this sense, being associated is only one of multiple factors. So, there are challenges in establishing a cause-effect relationship between the policy and any increase in competitiveness, requiring a wider appreciation of potential relationships.

The descriptive statistics presented in section 4 show that the productivity level of associated firms is higher than that of non-associated firms in both 2002 and 2008, as is both the absolute and relative productivity growth between these two years. Moreover firms within the CAs are shown to be more likely to invest in R\&D and to have technical and environmental quality certificates. This is in line with earlier findings in the Basque context. ARAGÓN et al. (2010), for example, compare the performance of associated-firms in two specific CAs with a control group of non-associated firms. Here, significant differences were found in areas of internationalisation, quality management certificates and R\&D expenditure (with better performance of associated-firms), although no differences were detected in terms of economic profitability. Also in the Second Competitiveness Report of the BASQUE INSTITUTE OF COMPETITIVENESS (2009), indicators of growth of sales (2003-2006), internationalization and innovation for the associated firms of all Basque CAs are compared with the mean of these indicators for the Basque manufacturing sector. The conclusion is that in all indicators associated firms perform better than non-associated ones.

Combining this evidence it is possible to build a strong case for positive impacts from the cluster policy: there are a series of symptoms suggesting that associated firms perform better than non-associated ones. Moreover, this impact is supported by the econometric analysis, where the positive and significant sign on the CLUSTER variable in several of the regressions suggests additionality in productivity performance from associating to a CA. What is more difficult, however, is to be categorical with regards to the direction of causality 
that leads to this apparent additionality. Indeed, our contextual knowledge of the policy and firms involved would suggest that the relationship runs in the inverse sense: firms that perform better in these various indicators are those most likely to associate to cluster associations, in part through pressure from policy-makers in promoting the policy among these firms (e.g. policy-makers, who avail of detailed statistics on business performance, invited these firms to associate before inviting any other firms). Thus care should be taken in making a straightforward interpretation on cause-effect additionality.

2. There could be other benefits from the cluster policy - different from those that can be specified in a formal model - that will be generated thanks to its systemic nature.

Firstly, there are difficulties in separating the impact of CA activities on the competitiveness of associated firms with spillover impacts on non-associated firms. For instance, if the CA works to improve the provision of training and skills, it generates positive effects not only for associated firms, but also for non-associated firms located in the Basque Country. This can be seen in the case of the Aeronautics CA, which develops aeronautics engineering modules in a joint project with the Engineering School in Bilbao. In addition, there could be knowledge spillovers to non-associated firms based on the development of new technologies or innovations; these may be developed through cooperation among CA members, and transferred to other firms through user-producer relationships.

Secondly, and less obviously, cluster policies can generate a series of other indirect benefits. For instance, in the context of the Basque cluster policy, we argue that there have been improvements in other policies through the learning process promoted among regional firms and policy-makers in the cluster policy framework. Basque CAs have maintained a close relationship with the DITT of the Basque Government, who has developed a matrix of 
'vertical' and 'horizontal' technicians to attend the meetings of the CAs. Vertical technicians have a general vision of the sector in which each CA operates, and horizontal technicians have a general vision of each strategic area (innovation, internationalization, quality). The knowledge developed among technicians can provide orientation on critical issues for each cluster. Also, the government develops direct knowledge about the main problems, activities and relationships in each sector and each area, which is a valuable input in designing industry policy in a whole range of other areas. For example, this matrix structure was crucial for the definition and implementation of the Innova-cooperation programme, which was launched to support cooperative innovation projects in 2008. As a result, this programme has generated space for bottom-up defined innovation projects.

Indeed, a main conclusion of ARANGUREN and NAVARRO's (2003) study was that while the direct effects of the policy were difficult to measure in terms of competitive upgrading, two positive effects were detected: First, the adaptation of other policies to the real needs of firms; and second, an improvement in the level of knowledge among firms about public policies. Related to this argument around the impact of cluster policies in improving the efficiency of other policies, ARANGUREN et al. (2010) argue that new governance models guided by transparency are converging with various public policies interacting in the same territory. So, from the very first moment, evaluation processes pursuing the better integration of policies can help to generate constant feedback for the agents that will improve the real outcomes of the various specific policies (NAUWELAERS and WINTJES, 2008; BORRÁS and TSAGDIS, 2008).

Other kinds of important benefits that cluster policies generate and are not captured by empirical analyses are the effects on building trust and social capital. These are key elements for sustained competitiveness in a territory, but take considerable time to build 
and develop impacts in more tangible areas. For instance, in the context of the Basque cluster policy, ITURRIOZ et al. (2006) and ARANGUREN et al. (2008) analyse the perceptions of CA members in the Paper cluster on the extent to which intangible outputs (networking, social capital and cooperation in strategic projects) and tangible results (improvements in firm competitiveness) were being reached. They conclude that although $80 \%$ of the association members agreed that the activities developed in the association had influenced their competitiveness, only 10\% valued such impact as high or very high. However $70 \%$ of members agreed that the association had facilitated cooperation, generated trust and helped to share knowledge and experiences. These are behavioural additionalities that over time can be harnessed to support competitiveness additionalities, and have been the focus in the development of a social capital approach for policy learning applied to the aeronautics cluster (ARAGÓN et al., 2012).

3. There could be a range of other problems related to the limitations of the available indicators in understanding complex behaviour and relationships.

It is considered that the associated firms are the beneficiaries of the policy. However, the aims that the associated firms pursue when they associate to a CA are not evident. If their motivations are based on their real interest for the potential that cooperation has for their competitiveness, and consequently they act proactively in the association, then their membership is more likely to have an impact on competitiveness. In contrast, if the members do not believe in cooperation and join primarily because others did or because policy-makers put pressure on them, one might expect membership to have a lower effect on competitiveness. Thus different and hidden motivations may produce differentiated effects that are impossible for an empirical analysis to capture. 
In the case of the Basque Paper Cluster, for example, ITURRIOZ et al. (2006) conclude that associated firms who believed cooperation to be strategic to increase their competitiveness both had higher values in social capital indicators and perceived that the CA effect on their competitiveness was higher. Meanwhile, those members that had no clear motivations for membership had lower levels of social capital and perceptions on impacts on competitiveness. Similar findings are also evident from a participative evaluation process with Basque Aeronautics cluster (ARAGÓN et al., 2012). Thus in making an evaluation of the policy we should not consider all members as the same, because the effect of the cluster policy on supported-firms' competitiveness does not depend only on the payment of a quota (which is the only obligation of a member), but also on the propensity to participate actively in the CA activities. Behavioural aspects are critical, yet unfortunately it is very difficult to uncover and integrate such information in an empirical study such as that conducted in section 4 .

Indeed, improvement in competitiveness could be measured with different indicators. In our case we have used improvement in value-added per employee. However the policy can also have intermediate impacts on firm behaviour with regards internationalisation, innovation, quality and training, through projects in which the CAs take the role of cooperation facilitators. While we have included these behavioural indicators in the empirical analysis, the indicators available are severely limited. For example we only know whether or not a firm conducts R\&D, rather than how much they conduct, or whether or not they have obtained quality certificates. We also have no data on firm behaviour with regard to internationalisation.

Finally, in line with our statistical analysis, DE LA MAZA et al. (2008) also illustrate that the likelihood of CA membership is significantly correlated with firm size, and that larger 
firms are more likely to invest in R\&D and have quality certificates, etcetera. So it seems that the cluster policy includes mostly larger firms, and does not extend well to smaller firms. This is difficult to control for in our quantitative analysis, given that the dependent variable is constructed from a size variable (employment). Moreover it is linked to our earlier argument regarding the problems of inferring causality in such policies, where there may be pressure from policy-makers on certain lead firms to sign up to the policy.

\section{CONCLUSIONS}

In this paper we have illustrated and explored the methodological challenges in evaluating soft, relationship-oriented policies. Our contribution has focussed specifically on an empirical and contextual examination of one of the longest-standing cluster policies, that of the Basque Country region in Spain.

Our empirical analysis presented a statistical overview of the characteristics and performance of two groups of industrial firms; those that associated to CAs (and have been supported by the cluster policy), and those that have not. In particular, associated firms demonstrate superior levels and growth of productivity, and appear more likely to have obtained quality certificates and to have invested in R\&D. An econometric analysis using two different sample methodologies - 'full sample' and 'matched sub-sample' - shows mixed results across different models and time periods. Overall we can say that there is weak evidence that the cluster policy has had a positive impact on firm-level productivity.

While the results support the existence of additionality associated with the policy to a limited extent, their nuanced nature urges caution in using this statistical analysis in isolation to evaluate the policy. Indeed the primary purpose of the paper is not to make an 
empirical evaluation of this specific policy, but rather to illustrate and explore the inherent difficulties in evaluating cluster policies. Using context-specific knowledge of the policy in question, we have undertaken a complementary qualitative analysis that has highlighted and clarified the limitations of the empirical analysis. As such the paper responds to an important need in the evaluation of cluster policies, showing how traditional empirical techniques can be usefully integrated with qualitative, contextual elements capable of viewing the policy from a wider perspective. Due to the limitations in indicators and datasets, but mainly to analytical difficulties in establishing simple cause-effect relationships in systemic, relationship-oriented policies, it is crucial to nest different methodological approaches to the evaluation of such policies in this way.

In this sense we argue that the empirical analysis conducted here should be treated as an important input in a wider reflection among policy stake-holders in the Basque Country, alongside a range of more qualitative studies, including case studies of the actual processes occurring in specific cluster associations (ARAGÓN et al., 2012a, 2012b).

More generally our analysis raises a number of key issues for future research around the evaluation and impacts of cluster policies. In particular it suggests the importance of combining a statistical overview of firm-related and observable outcomes with: (i) a detailed understanding of the actual policy itself, and in particular of where it fits in the overall system of policies that co-exist in a specific territory; and (ii) detailed case analysis that is capable of uncovering further information around firm behaviour and motivation with respect to the policy. Only by doing this in the context of each policy it is possible to counter-balance the limitations of both the data and the suitability of statistical techniques for uncovering impacts of cooperation-based, systemic policies. 


\section{NOTES}

1. Cluster policies are a type of public policy that target the promotion of clusters in specific geographical contexts. In the context of the Basque Country, the focus of the empirical part of this paper, cluster policies take the form of the creation of cluster associations that promote the development of joint member initiatives in key areas such as innovation, quality and internationalisation.

2. For a methodological overview of the evaluation of cluster policies see SCHMIEDEBERG (2010).

3. See Table 3 for an explanation of variables.

4. Results are omitted here due to space considerations but can be obtained upon request. The variables are described in the following section.

5. This variable is measured through two indicators: 1) SECAGG, which captures agglomeration economies based on sector concentration; 2) INDAGG, which captures agglomeration economies based on concentration in the four industrial parks in the Basque Country.

6. Internationalization could not be included due to lack of appropriate data.

\section{ACKNOWLEDGEMENTS}

We would like to acknowledge Asier Murciego for his support with database management and Juan José Gibaja-Martíns and Esteban Lafuente for their advice on statistical techniques and comments on earlier versions of the paper. We also thank the referees and the editors of Regional Studies for the high quality comments and suggestions that have helped to improve the value of this paper. The usual disclaimers apply. Ferran VendrellHerrero acknowledges financial support from SEJ 2007-67895-Co4. 


\section{REFERENCES}

AHEDO M. (2004) Cluster Policy in the Basque Country (1991-2002) Constructing "Industry-Government" Collaboration through Clusterassociations, European Planning Studies 12, 1097-1113.

ARAGÓN, C., ARANGUREN, M-J., ITURRIOZ, C. and WILSON, J. R. (2012a) A Social Capital Approach for Network Policy Learning: The Case of an Established Cluster Initiative, European Urban and Regional Studies, forthcoming.

ARAGÓN, C., ARANGUREN, M-J., ITURRIOZ, C. and WILSON, J. R. (2012b) A participative Methodology for Evaluating the Cluster Policy of the Basque Country, in COOKE, P. et al. (eds) Innovation, Global Change and Territorial Resilience. Edward Elgar, Cheltenham.

ARAGÓN, C., ARANGUREN, M-J. and ITURRIOZ, C. (eds.) (2010) Evaluación de políticas clúster: El caso del País Vasco, Bilbao: Deusto Publicaciones.

ARANGUREN M.J. and NAVARRO I. (2003) La política de clusters en la Comunidad Autónoma del País Vasco: una primera valoración, Ekonomiaz $53,90-113$

ARANGUREN M.J., ITURRIOZ C. and WILSON, J. (2008) Networks, Governance and Economic Development, Edward Edgar, Cheltenham.

ARANGUREN M.J., DE LA MAZA X., PARRILLI M.D., and WILSON J.R. (2009) Asociaciones clúster de la CAPV: desempeño y retos, San Sebastián, Serie Clústeres, Desarrollo Regional e Innovación, Basque Institute of Competitiveness - Orkestra. 
ARANGUREN M.J, LARREA M. and WILSON J.R. (2010) Trayectorias de cambio en la gobernanza: experiencias en asociaciones cluster y redes comarcales en el País Vasco, Ekonomiaz 74, 160-177.

ASHEIM, B. (2010) A new regional innovation policy, in PARRILLI M.D. (Ed) Innovación y aprendizaje: lecciones para el diseño de políticas. Innobasque IVC, Bilbao \& San Sebastian.

AUDRETSCH D.B. and FELDMAN M.P. (1996) R\&D spillovers and the geography of innovation and production, American Economic Review 86, 253-273.

BASQUE INSTITUTE OF COMPETITIVENESS (2009) Second Competitiveness Report. Orkestra-Basque Institute of Competitiveness, San Sebastián (Spain). BECATTINI G. (1991) Italian Industrial Districts; Problems and Perspectives, International Studies of Management and Organization 21, 83-90.

BELUSSI F. (2006) In search of a useful theory of spatial clustering, in ASHEIM B. T. Asheim, COOKE P. and MARTIN R. (eds) Clusters and Regional Development, pp. 69-89. Routledge, London.

BENNEWORTH P. and CHARLES D. (2001) Bridging cluster theory and practice: learning from the cluster policy cycle, in DEN HERTOG et al. (Eds) Innovative Clusters: Drivers of National Innovation Systems. OECD Publishing, Paris.

BORRÁS S. and TSAGDIS D. (2008) Cluster Policies in Europe - firms, institutions, and governance. Edward Elgar, Cheltenham.

BROWN R. (2000) Cluster Dynamics in Theory and Practice with Application to Scotland, Regional and Industrial Policy Research Paper, No 38, European Policies Research Centre, University of Strathclyde. 
COOKE P., GOMEZ-URANGA M. and ETXEBARRIA G. (1998) Regional systems of innovation: Institutions and organisational dimensions, Research Policy 26, 475-491.

DE LA MAZA X., ARANGUREN M. J. and MURCIEGO A. (2008) Small enterprises involvement within the Basque cluster policy: a new challenge, paper presented at the 11th EUNIP International Conference, San Sebastian, 10-12 September 2008.

DE LA MAZA X., VENDRELL-HERRERO, F. and WILSON, J. R. (2012) Where is the value of cluster associations for SMEs, Intangible Capital 8(2), 472496.

DEHEIJA, R. and WAHBA, S. (2002) Propensity Score Matching Methods for Nonexperimental Causal Studies, Review of Economics and Statistics 84, 151161.

DIEZ M. A. (2002) Evaluating new regional policies. Reviewing the theory and practice, Evaluation 8, 285-305.

DURANTON G. and PUGA D. (2001) Nursery Cities: Urban Diversity, Process Innovation, and the Life Cycle of Products, American Economic Review 91, $1444-1477$.

FREEMAN C. (1987) Technology Policy and Economic Performance. Lessons from Japan. Pinter, London.

FREEMAN C. (1991) Networks of innovators: a synthesis of research issues, Research Policy 20, 499-514.

FROMHOLD-EISEBITH M. and EISEBITH G. (2005) How to instituzionalize innovative clusters? Comparing explicit top down and implicit bottom-up approaches, Research Policy 34, 1250-1268. 
FROMHOLD-EISEBITH M. and EISEBITH G. (2008) Looking Behind Facades: Evaluating Effects of (Automotive) Cluster Promotion, Regional Studies 42, $1343-1356$.

GEORGHIOU L. (2004) Evaluation of Behavioural Additionality. Concept Paper. Making the Difference. The Evaluation of "Behavioural Additionality". OECD, Paris, OECD Publishing.

GLAESER E.L., KALLAL H.D., SCHEINKMAN J.A. and SHLEIFER A. (1992) Growth in cities, Journal of Political Economy 100, 1126-1152.

GREUNZ L. (2004) Industrial structure and innovation. Evidence from European regions, Journal of Evolutionary Economics 14, 563-592.

HECKMAN J. (1979) Sample selection bias as a specification error, Econometrica 47, 153-61.

HUBER P. J. (1967) The behaviour of maximum-likelihood estimates under non-standard conditions. Proceedings of the Fifth Berkeley Symposium on Mathematical Statistics and Probability, 1, 221-223.

HUGGINS R. (2001) Inter-firm network policies and firm performance: Evaluating the impact of initiatives in the United Kingdom, Research Policy 30, $443-458$.

ISAKSEN A. and HAUGE E. (2002) Regional Clusters in Eurpope, Observatory of European SMEs 2002, n. 3. Office for Offical Publications of the European Communities, Luxembourg.

ITURRIOZ C., ARANGUREN M.J., ARAGÓN C. and LARREA M. (2006) La política industrial de cluster/redes mejora realmente la competitividad empresarial. Resultados de la evaluación de dos experiencias en la CAPV, Ekonomiaz 60. 
KETELS C. (2004) European Clusters, in Structural Change in Europe Innovative City and Business Regions. Harvard Businnes School, Boston.

LAGENDIJK A. and CORNFORD J. (2000) Regional institutions and knowledge-tracking new forms of regional development policy, Geoforum 31, 209-218.

LEUVEN E. and SIANESI B. (2003) PSMATCH2: Stata module to perform full Mahalanobis and propensity score matching, common support graphing, and covariate inbalance testing. Statistical Software Components. S432001, Boston College Department of Economics.

LORENZEN M. (2005) Editorial: Why do clusters change, European Urban and Regional Studies 12, 203-208.

LUNDVALL B.A. (1992) National Systems of Innovation. Towards a Theory of Innovation and Interactive Learning. Pinter, London.

MARSHALL A. (1907) Principles of Economics. Macmillan, London.

MARSHALL A. (1919) Industry and Trade. Macmillan, London.

MARTIN F., MAYER T. and MAYNERIS F. (2011a) Public Support to Clusters: A Firm level study of French, Regional Science and Urban Economics 41, 108-123.

MARTIN F., MAYER T. and MAYNERIS F. (2011b) Spatial Concentration and Firm-Level Productivity in France, Journal of Urban Economics , Vol. 69 (2), 182-195.

MARTIN R. and SUNLEY P. (2003) Deconstructing clusters: chaotic concept or policy panacea?, Journal of Economic Geography 3, 5-35. 
MCDONALD F., HUANG Q., TSAGDIS D. and TÜSELMANN H. J. (2007) Is there Evidence to Support Porter-type Cluster Policies? Regional Studies, 3949.

NAUWELAERS C. and WINTJES R. (2008) Innovation policy in Europe Measurement and Strategy. Cheltenham, Edward Elgar.

NELSON R. (1993) National Innovation Systems: A Comparative Analysis. Oxford University Press, Oxford.

OECD (1999) Boosting Innovation: The Cluster Approach. OECD Publishing, Paris.

OECD (2007) Competitive Regional Clusters. National Policy Approaches. OECD Publishing, Paris.

OXFORD RESEARCH (2008) Cluster Policy in Europe: A Brief Summary of Cluster Policies in 31 European Countries. Report for the Europe Innova Cluster Mapping Project, available at www.clusterobservatory.eu

PACI R. and USAI S. (2000) The Role of Specialisation and Diversity Externalities in the Agglomeration of Innovative Activities, Rivista Italiana degli Economisti 5, 237-268.

PARRILLI, M.D. (2004) A stage and eclectic approach to industrial district development, European Planning Studies, Vol. 12 (8), 1115-1130.

PARRILLI M.D. (2008) Introduction, in PARRILI M.D., BIANCHI P. and SUGDEN R. (Eds) High technology, productivity and networks: a systemic approach to SME development. Palgrave-Macmillan, Basingstoke.

PIORE, M.J. and SABEL, C.F. (1984). The Second Industrial Divide: Possibilities for Prosperity. Basic Books, New York 
PITELIS C., SUGDEN R. and WILSON J. (2006) Globalisation and Governance, The development of urban and regional economies. Edward Elgar, UK PORTER M.E. (1990) The Competitive Advantage of Nations. Free Press, New York

PORTER M.E. (1998) Clusters and the New Economics of Competition, Harvard Business Review 76, 77-91.

PORTER M.E. (2003) The performance of regions, Regional Studies 37 (6/7), 549-578.

PORTER M.E. and KETELS M. (2009) Clusters and Industrial Districts: Common Roots, Different Perspectives, in BECATINNI, G. et al. (eds) Handbook of Industrial Districts. Edward Elgar, Cheltenham.

POWELL W.W., DOPUT, K.W. and SMITH-DOERR L. (1996) Interorganisational collaboration and the locus of innovation: networks of learning in biotechnology. Administrative Science Quarterly 41, 116-145.

PYKE F., BECATTINI G. and SENGENBERGER W. (1990) Industrial districts and interfirm co-operation in Italy. International Institute for Labor Studies, Geneva.

RAINES P. (2002) The Challenge of Evaluating Cluster Behaviour in Economic Development Policy. Paper presented to the International RSA Conference: Evaluation and EU regional policy: New questions and challenges.

RODRÍGUEZ-POSE A. and GILL N. (2003) The Global Trend Towards Devolution and Its Implications, Environment and Planing C: Government and Policy 21, 333-351.

ROSENBAUM P.R. and RUBIN D.B. (1983) The Central Role of the Propensity Score in Observational Studies for Causal Effect, Biometrika 70 (1), 41-55. 
SAXENIAN A.L. (1994) Regional Advantage: Culture and Competition in Silicon Valley and Route 128. Harvard University Press, Cambridge, MA.

SMITH K. (1994) Interactions in knowledge systems: foundations, policy implications and empirical methods. STEP Group Report, Oslo.

SCHMIEDEBERG C. (2010) Evaluation of cluster policy: a methodological overview, Evaluation 16(4), 389-412.

SCHMITZ H. (1995) Collective Efficiency: Growth Path for Small Scale Industry, Journal of Development Studies 31, 529-586.

SPENCER G.M, VINODRAI T., GERTLER, M.S. and WOLFE D.A. (2009) Do Clusters Make a Difference? Defining and Assesing their Economic Performance, Regional Studies 44, 697-715.

SÖLVELL Ö., LINDQUIST G. and KETELS C. (2003), The Cluster Initiative Greenbook. Bromma tryck AB, Stockholm

STOREY, D. J. (2000), Six Steps to Heaven: Evaluating the Impact of Public Policies to Support Small Businesess in Developed Economies, in SEXTON, D.L. and LANDSTRÖM, H. (Eds) The Blackwell Handbook of Entrepreneurship. Blackwell Publishers, Oxford.

STOREY, D.J. (2004), Evaluation of SMEs policies and programmes. Document prepared in cooperation with the SME Unit of the OECD Secretariat for the $2^{\text {nd }}$ OECD Conference of Ministres Responsible for SMEs held in Istanbul, 23 June 2004.

TERSTRIEP J. (2007), Balance Scorecard, measuring CM performance, Europe Innova, Innovation and Clusters, Nice, France. 
TUROK I. (1990), Evaluation and accountability in spatial economic policy: a review of alternative approaches, Scottish Geographical Magazine 106(1), 411.

VON HIPPEL E. (1988), The sources of innovation. New York, Oxford Univ. Press.

WHITE H. (1982) Maximum likelihood of misspecified models. Econometrica $50,1-25$.

WOOLDRIDGE J.M. (2003) Cluster-Sample Method in Applied Econometrics, American Economic Review 93(2), 133-138. 
Table 1: Cluster Associations of the Basque Country

\begin{tabular}{lccc}
\hline Cluster Association & Created & Members & Coordinated by \\
\hline Home Appliances & 1992 & 11 & Dept. of Industry \\
Machine-tools & 1992 & 94 & Dept. of Industry \\
Automotive & 1993 & 90 & Dept. of Industry \\
Environment & 1995 & 93 & Dept. of Industry \\
Energy & 1996 & 78 & Dept. of Industry \\
Telecommunications & 1996 & 238 & Dept. of Industry \\
Port of Bilbao & 1997 & 151 & Dept. of Industry \\
Maritime & 1997 & 192 & Dept. of Industry \\
Aeronautics & 1997 & 36 & Dept. of Industry \\
Paper & 1998 & 20 & Dept. of Industry \\
Audiovisual & 2004 & 54 & Dept. of Industry \\
Transports\&Logistics & 2005 & 88 & Dept. of Transport \\
\hline Total & & 1145 & \\
\hline
\end{tabular}

Source: own elaboration 
Table 2: Industrial Sectors

\begin{tabular}{ll}
\hline $\begin{array}{l}\text { Variable } \\
\text { Name }\end{array}$ & \multicolumn{1}{c}{$\begin{array}{c}\text { Sub Sector } \\
\text { Codes }\end{array}$} \\
\hline SECTOR1 Food, drink and tobacco & 15,16 \\
SECTOR2 Textiles & $17,18,19$ \\
SECTOR3 Wood and paper & $20,21,22,36$ \\
SECTOR4 Petro-chemicals & 23,24 \\
SECTOR5 Plastics and minerals & 25,26 \\
SECTOR6 Metals & 27,28 \\
SECTOR7 Industrial equipment, information and electronics & $29,30,31,32,33$ \\
SECTOR8 Recycling & 37 \\
SECTOR9 Energy and Water & 40,41 \\
SECTOR10 Transport & $49,50,51,52,53$ \\
SECTOR 11 Audiovisual & $59,60,61$ \\
\hline
\end{tabular}

Source: own elaboration 
Table 3: Explanation of Variables

\begin{tabular}{|c|c|c|c|c|}
\hline VARIABLE & SHORT NAME & AREA & TYPE & EXPLANATION \\
\hline Labour Productivity level & $\begin{array}{l}\text { PRODUCTIVITY } \\
\text { (Y in Equations) }\end{array}$ & $\begin{array}{l}\text { COMPETITIVEN } \\
\text { ESS }\end{array}$ & Dependent & $\begin{array}{l}\text { (Value } \\
\text { Added/Employees) }\end{array}$ \\
\hline Association Membership & CLUSTER & $\begin{array}{l}\text { ASSOCIATIONIS } \\
\mathrm{M}\end{array}$ & Independent & $\begin{array}{l}\text { Dummy: } 1 \text { CA member; } 0 \\
\text { non-member }\end{array}$ \\
\hline $\begin{array}{l}\text { Agglomeration in } \\
\text { Industrial Park by county }\end{array}$ & INDAGG & $\begin{array}{l}\text { AGGLOMERATI } \\
\text { ON }\end{array}$ & Independent & $\begin{array}{l}\text { Index }=[(\text { Ratio: industry } \\
\text { firms in county }) /(\text { Ratio: } \\
\text { industry firm in Basuqe } \\
\text { Country })]\end{array}$ \\
\hline R\&D Activity by county & R\&DCOUNT & $\begin{array}{l}\text { AGGLOMERATI } \\
\text { ON }\end{array}$ & Independent & $\begin{array}{l}\text { Number of firms doing } \\
\text { R\&D by county. }\end{array}$ \\
\hline $\begin{array}{l}\text { Sectoral Agglomeration } \\
\text { by county }\end{array}$ & SECAAG & $\begin{array}{l}\text { AGGLOMERATI } \\
\text { ON }\end{array}$ & Independent & $\begin{array}{l}\text { Index }=[(\text { Ratio: sector } \\
\text { firms in county }) /(\text { Ratio: } \\
\text { sector firm in Basuqe } \\
\text { Country })]\end{array}$ \\
\hline Techonolgy management & $R \& D$ & POLICY AREA & Independent & $\begin{array}{l}\text { Dummy, } 1 \text { doing R\&D; } 0 \\
\text { non-R\&D }\end{array}$ \\
\hline $\begin{array}{l}\text { Technical Quality } \\
\text { management }\end{array}$ & TMQ & POLICY AREA & Independent & $\begin{array}{l}\text { Dummy, } 1 \text { doing TMQ; } 0 \\
\text { non-TQM }\end{array}$ \\
\hline $\begin{array}{l}\text { Environmental } \\
\text { Management Quality }\end{array}$ & EMQ & POLICY AREA & Independent & $\begin{array}{l}\text { Dummy, } 1 \text { doing EMQ; } 0 \\
\text { non-EMQ }\end{array}$ \\
\hline $\begin{array}{l}\text { Cost per employee in } \\
\text { manufacturing firms }\end{array}$ & LABCOST & FIRM & Independent & \\
\hline GDP per county & GDPPC & FIRM & Independent & \\
\hline Public Limited Company & LEGAL-PLC & FIRM & Control & Dummy \\
\hline Private Company & $\begin{array}{l}\text { LEGAL- } \\
\text { PRIVATE }\end{array}$ & FIRM & Control & Dummy \\
\hline Cooperative & LEGAL-COOP & FIRM & Control & Dummy \\
\hline Other & LEGAL-OTHER & FIRM & Control & Dummy \\
\hline $\begin{array}{l}\text { Number of employees in } \\
2002\end{array}$ & EMP2002 & FIRM & Control & \\
\hline $\begin{array}{l}\text { Age of the firm since } \\
\text { creation in } 2002\end{array}$ & AGE2002 & FIRM & Control & \\
\hline
\end{tabular}


Table 4: Summary Statistics for CA and Non-CA firms (2002 and 2008) for the total and matched samples

\begin{tabular}{|c|c|c|c|c|}
\hline & \multicolumn{2}{|c|}{ TOTAL SAMPLE } & \multicolumn{2}{|c|}{ MATCHING SUB-SAMPLE } \\
\hline Variable & $\begin{array}{l}\text { Mean CA firms (176 } \\
\text { firms) }\end{array}$ & $\begin{array}{l}\text { Mean non CA firm } \\
\text { (5349 firms) }\end{array}$ & $\begin{array}{l}\text { Mean CA firm (120 } \\
\text { firms) }\end{array}$ & $\begin{array}{l}\text { Mean non CA firm } \\
\text { (120 firms) }\end{array}$ \\
\hline Employment 2002 & $\begin{array}{l}89.80952 \\
(135.7756)\end{array}$ & $\begin{array}{l}24.09572 \\
(96.22744)\end{array}$ & $\begin{array}{l}86.87603 \\
(133.9032)\end{array}$ & $\begin{array}{c}117.0579 \\
(486.8985)\end{array}$ \\
\hline Employment 2008 & $\begin{array}{l}114.2619 \\
(242.5338)\end{array}$ & $\begin{array}{l}26.38441 \\
(110.639)\end{array}$ & $\begin{array}{l}112.4876 \\
(244.0596)\end{array}$ & $\begin{array}{l}114.7438 \\
(430.964)\end{array}$ \\
\hline $\begin{array}{l}\text { Productivity } 2002 \\
\text { (thousands of euros) }\end{array}$ & $\begin{array}{c}66417.61 \\
(83102.06)\end{array}$ & $\begin{array}{c}49191.41 \\
(129245.6)\end{array}$ & $\begin{array}{c}67073.93 \\
(84475.62)\end{array}$ & $\begin{array}{c}74347.81 \\
(152873.4)\end{array}$ \\
\hline $\begin{array}{l}\text { Productivity } 2008 \\
\text { (thousands of euros) }\end{array}$ & $\begin{array}{c}97175.86 \\
(323143.8)\end{array}$ & $\begin{array}{c}47150.1 \\
(135080.9)\end{array}$ & $\begin{array}{c}100424.9 \\
(329350.3)\end{array}$ & $\begin{array}{c}58616.42 \\
(68947.39)\end{array}$ \\
\hline $\begin{array}{l}\text { Absolute productivity } \\
\text { growth (2002-2008) }\end{array}$ & $\begin{array}{l}30735.38 \\
(255070.8)\end{array}$ & $\begin{array}{l}-1283.796 \\
(120685.9)\end{array}$ & $\begin{array}{l}33327.87 \\
(259743.4)\end{array}$ & $\begin{array}{c}-15757.85 \\
(127213)\end{array}$ \\
\hline $\begin{array}{l}\text { Relative productivity } \\
\text { growth (2002-2008) }\end{array}$ & $\begin{array}{l}0.2469975 \\
(1.675749)\end{array}$ & $\begin{array}{c}0.215822 \\
(3.948444)\end{array}$ & $\begin{array}{l}0.2702284 \\
(1.698208)\end{array}$ & $\begin{array}{l}-.0004659 \\
(0.4466954)\end{array}$ \\
\hline $\begin{array}{l}\text { Sectoral Agglomeration } \\
2002\end{array}$ & $\begin{array}{c}1.399752 \\
(0.8267038)\end{array}$ & $\begin{array}{c}1.618258 \\
(3.477684)\end{array}$ & $\begin{array}{c}1.364963 \\
(0.8171688)\end{array}$ & $\begin{array}{c}1.264243 \\
(0.7735552)\end{array}$ \\
\hline $\begin{array}{l}\text { Sectoral Agglomeration } \\
2008\end{array}$ & $\begin{array}{c}1.360869 \\
(0.8258885)\end{array}$ & $\begin{array}{c}1.70524 \\
(3.889788)\end{array}$ & $\begin{array}{c}1.385825 \\
(0.8366609)\end{array}$ & $\begin{array}{c}1.281367 \\
(0.7911502)\end{array}$ \\
\hline $\begin{array}{l}\text { Industrial Agglomeration } \\
\qquad 2002\end{array}$ & $\begin{array}{c}1.077304 \\
(0.2020556)\end{array}$ & $\begin{array}{c}1.091686 \\
(0.2919163)\end{array}$ & $\begin{array}{c}1.078819 \\
(0.2194203)\end{array}$ & $\begin{array}{l}1.061994 \\
(0.200667)\end{array}$ \\
\hline $\begin{array}{l}\text { Industrial Agglomeration } \\
2008\end{array}$ & $\begin{array}{c}1.076718 \\
(0.2189311)\end{array}$ & $\begin{array}{c}1.100266 \\
(0.3058015)\end{array}$ & $\begin{array}{c}1.078819 \\
(0.2194203)\end{array}$ & $\begin{array}{c}1.064939 \\
(0.2123224)\end{array}$ \\
\hline $\mathrm{R} \& \mathrm{D}$ performance & $\begin{array}{c}.6590909 \\
(0.6909433)\end{array}$ & $\begin{array}{c}.087306 \\
(0.2823094)\end{array}$ & $\begin{array}{c}0.625 \\
(0.6359338)\end{array}$ & $\begin{array}{c}0.575 \\
(0.4964157)\end{array}$ \\
\hline $\begin{array}{c}\text { Technical Management } \\
\text { Quality }\end{array}$ & $\begin{array}{c}.6022727 \\
(0.5764873)\end{array}$ & $\begin{array}{c}.1546083 \\
(0.3777514)\end{array}$ & $\begin{array}{c}0.575 \\
(0.5892953)\end{array}$ & $\begin{array}{c}0.625 \\
(0.5660196)\end{array}$ \\
\hline $\begin{array}{c}\text { Environmental } \\
\text { Management Quality }\end{array}$ & $\begin{array}{l}.2840909 \\
(0.5746823)\end{array}$ & $\begin{array}{c}.0334642 \\
(0.2014392)\end{array}$ & $\begin{array}{c}0.25 \\
(0.4348283)\end{array}$ & $\begin{array}{c}0.25 \\
(0.5225985)\end{array}$ \\
\hline Age of the firm in 2002 & $\begin{array}{l}19.53409 \\
(14.46252)\end{array}$ & $\begin{array}{c}12.4337 \\
(11.17664)\end{array}$ & $\begin{array}{c}18.89167 \\
(14.63896)\end{array}$ & $\begin{array}{c}20.73333 \\
(16.22413)\end{array}$ \\
\hline $\begin{array}{l}\text { Labour Cost per } \\
\text { Employee (2008) }\end{array}$ & $\begin{array}{l}32764.89 \\
(2309.37)\end{array}$ & $\begin{array}{c}32625 \\
(2187.427)\end{array}$ & $\begin{array}{l}32795.54 \\
(2335.618)\end{array}$ & $\begin{array}{l}32693.03 \\
(2339.724)\end{array}$ \\
\hline $\begin{array}{l}\text { R\&D firms per county } \\
\text { (2008) }\end{array}$ & $\begin{array}{c}.7974882 \\
(0.4587098)\end{array}$ & $\begin{array}{l}.7759905 \\
(0.4389258)\end{array}$ & $\begin{array}{c}0.79875 \\
(0.4602615)\end{array}$ & $\begin{array}{l}.7449583 \\
(0.4244195)\end{array}$ \\
\hline GDP per county (2008) & $\begin{array}{c}31582.82 \\
(4129.539) \\
\end{array}$ & $\begin{array}{l}32870.95 \\
(6304.94) \\
\end{array}$ & $\begin{array}{c}31515.99 \\
(4108.203)\end{array}$ & $\begin{array}{c}30979.85 \\
(3954.954) \\
\end{array}$ \\
\hline
\end{tabular}

Standard Deviation in Parenthesis.

Source: SABI and Basque Institute of Statistics (DIRAE). Own elaboration. 
Table 5: Total Sample Regressions

\begin{tabular}{|c|c|c|c|c|c|}
\hline Variable & Productivit & $\begin{array}{l}\text { ity Level (2002) } \\
\text { OLS }\end{array}$ & $\begin{array}{c}\text { Productivity Level (2008) } \\
\text { HECKMAN }\end{array}$ & $\begin{array}{c}\text { Absolute Change Productivity } \\
\text { (2002-2008) } \\
\text { HECKMAN }\end{array}$ & $\begin{array}{c}\text { Relative Change Productivity } \\
\text { (2002-2008) } \\
\text { HECKMAN }\end{array}$ \\
\hline PRODUCTIVITY (2002) & & - & - & $-31850.75(6910.491)^{* * *}$ & - \\
\hline CLUSTER & 0.126645 & $(0.0546703)^{* *}$ & $0.1991121(0.0680074)^{* * *}$ & $136790.2(26508.46)^{* * *}$ & $2.029182(.5571858) * * *$ \\
\hline SECAGG & 0.0131957 & $(0.0036213)^{* * *}$ & $0.0131045(0.0037708)^{* * *}$ & $-809.0435 \quad(1439.15)$ & $-0.0302251 \quad(0.0307943)$ \\
\hline INDAGG & 0.131443 & $3(0.0838244)$ & $-0.1204316 \quad(0.0629817)$ & $7517.007 \quad 24158.03$ & $-0.2068405 \quad 0.5109007$ \\
\hline R\&DCOUNT & & - & $-0.0209989 \quad(0.0392948)$ & $6907.579 \quad(15196.29)$ & $0.6667616(0.3204283)^{* *}$ \\
\hline LABCOST & & & $0.7820038(0.1866901)^{* * *}$ & $470.5148 \quad(72445.28)$ & $-1.363747 \quad(1.520258)$ \\
\hline GDPPC & & & $0.2360569(0.0973983)^{* *}$ & $13584.17 \quad(38248.97)$ & $1.384597 \quad(.806304)$ \\
\hline$R \& D$ & 0.0917459 & $(0.0208746)^{* * *}$ & $0.1481729(0.0388845)$ *** & $-12099.46 \quad(14652.36)$ & $-.3107275(0.3158703)$ \\
\hline TMQ & 0.1253969 & $(0.0243324)^{* * *}$ & $0.0833129(0.0296925)^{* * *}$ & $-4085.483(11190.22)$ & $-.2036254 \quad(0.241584)$ \\
\hline EMQ & 0.2088809 & $(0.0428216)^{* * *}$ & $0.1848115(0.0521633)^{* * *}$ & $-25598.26 \quad(19820.77)$ & $-.4459853 \quad(0.425851)$ \\
\hline LEGAL-PLC & -0.2071577 & $(0.0217903)^{* * *}$ & $-0.1409415(0.0246235)^{* * *}$ & $8718.305 \quad$ (9393.785) & $.4097968 \quad(0.2006239)^{* *}$ \\
\hline LEGAL-COOP & -0.2813836 & $(0.0880041)^{* * *}$ & $-1.067878 \quad(0.2827518)^{* * *}$ & $-74438.1 \quad(107422.1)$ & $-1.71285 \quad(2.318955)$ \\
\hline LEGAL-OTHER & 0.3237605 & $(0.0368256)^{* * *}$ & $0.0427742 \quad(0.6236249)$ & $9692.079 \quad(236727.3)$ & $0.0582914 \quad(5.115704)$ \\
\hline CONSTANT & 10.46423 & $(0.1007892)^{* * *}$ & $0.0610984 \quad(0.2507504)$ & $229891.9 \quad(846820.7)$ & $-0.0983824 \quad(17.83086)$ \\
\hline CLUSTER & & - & $0.2396^{* *}(0.1049)$ & $0.2555^{* *}(0.1057)$ & $0.2555 * *(0.1057)$ \\
\hline AGE AT 2002 & & - & $0.0032 * *(0.0015)$ & $0.0030 * *(0.0015)$ & $0.0030 * *(0.0015)$ \\
\hline LABOUR AT 2002 & & - & $-0.0008(0.001)$ & $-0.0006(0.0016)$ & $-0.0006(0.0016)$ \\
\hline CONSTANT & & - & $0.0611(0.2507)$ & $0.1788(0.2517)$ & $0.1788(0.2517)$ \\
\hline MILLS LAMBDA & & - & $-0.02289(0.1907)$ & $-83340.01(70834.11)$ & $1.119(1.517)$ \\
\hline R-Squared & & 0.1131 & 0.1219 & 0.0607 & 0.0516 \\
\hline Observations & & 5525 & 5525 & 5525 & 5525 \\
\hline Censored Obs & & 0 & 2093 & 2093 & 2093 \\
\hline Uncensored Obs & & 5525 & 3432 & 3432 & 3432 \\
\hline
\end{tabular}

Level of statistical significance: $* * * 1 \%, * * 5 \%$. Robust Standard errors in parenthesis. For Legal Categorical variables we use as a reference group LEGAL-PC. In the Main model we omitted the results concerning sector categorical variables. In the selection model we omitted sector and county categorical variables.

Source: SABI and Basque Institute of Statistics (DIRAE). Own elaboration. 
Table 6: Matched Sub-Sample Regression

Level of statistical significance: $* * * 1 \%, * * 5 \%$. Robust Standard errors in parenthesis. For Legal Categorical

\begin{tabular}{|c|c|c|c|c|}
\hline Variable & $\begin{array}{c}\text { Productivity Level (2002) } \\
\text { OLS }\end{array}$ & $\begin{array}{c}\text { Productivity Level (2008) } \\
\text { OLS }\end{array}$ & $\begin{array}{c}\text { Absolute Change Productivity } \\
\text { (2002-2008) } \\
\text { OLS }\end{array}$ & $\begin{array}{c}\text { Relative Change Productivity } \\
(2002-2008) \\
\text { OLS } \\
\end{array}$ \\
\hline PRODUCTIVITY (2002) & - & - & $\begin{array}{ll}-127667.8 & (249855.5)\end{array}$ & - \\
\hline CLUSTER & $0.0762188 \quad(0.064834)$ & $0.2751998 \quad(0.1134)^{* *}$ & $181702.5 \quad(107724.7)$ & $2.341045 \quad(1.64786)$ \\
\hline SECAGG & $-0.0739122 \quad(0.031082)^{* *}$ & $-0.0438427 \quad(0.0518549)$ & $-83340.35 \quad(83348.33)$ & $-1.269166(1.033238)$ \\
\hline INDAGG & $.5167454(0.1133004)^{* * * *}$ & $0.1356881 \quad(0.2026466)$ & $717577.8 \quad(445056.1)$ & $11.24779 \quad(5.859401)$ \\
\hline R\&DCOUNT & & $0.0163377 \quad(0.0692279)$ & $57722.82 \quad(76421.42)$ & $1.029072 \quad(1.068527)$ \\
\hline LABCOST & & $0.4700288 \quad(0.2627074)$ & $-806814.6(379590.3)$ & $-14.62238 \quad(5.569728)^{* *}$ \\
\hline GDPPC & & $-0.1349679 \quad(0.1087063)$ & $582048.8(248945.3)^{* *}$ & $9.475191(3.795523)^{* *}$ \\
\hline$R \& D$ & $0.1137998(0.0472617)^{* *}$ & $0.240798(0.0644479)^{* *}$ & $-53499.94 \quad(54207.06)$ & $-0.7911676(1.514126)$ \\
\hline TMQ & $0.001639 \quad(0.0223217)$ & $-0.0337848 \quad(0.0514802)$ & $-15358.65 \quad(42526.91)$ & $-0.7166057 \quad(0.448759)$ \\
\hline EMQ & $0.3068834(0.0414588)^{* * *}$ & $0.1446805 \quad(0.1305522)$ & $-176611.3(91132.21)$ & $-3.660933 \quad(2.627192)$ \\
\hline LEGAL-PLC & $-0.1448638(0.0471336)^{* * * *}$ & $-0.0330312 \quad(0.0455159)$ & $107097.6(41602.78)^{* *}$ & $1.496909 \quad(1.221162)$ \\
\hline LEGAL-COOP & $-0.4546674(0.0564471)^{* * * *}$ & $-0.4059245(0.1584067)^{* *}$ & $-83919.31 \quad(77150.54)$ & $-0.2254247 \quad(2.323611)$ \\
\hline LEGAL-OTHER & (omitted) & (omitted) & (omitted) & (omitted) \\
\hline CONSTANT & $10.17122 \quad(11.39798)$ & $6.913178 * * \quad(3.008208)$ & $30.15694 \quad(37.62014)$ & $43.29566 \quad(65.38855)$ \\
\hline R-Squared & 0.3467 & 0.6151 & .2357 & .1845 \\
\hline Observations & 240 & 240 & 240 & 240 \\
\hline
\end{tabular}

variables we use as a reference group LEGAL-PC. We omitted the results concerning sector categorical variables Source: SABI and Basque Institute of Statistics (DIRAE). Own elaboration. 